\title{
The Election of Primian of Carthage: The Beginning of the End of Donatist Christianity?
}

In the Roman North Africa of the fourth and early fifth centuries (in what are today the countries of Libya, Tunisia, Algeria, and Morocco) there existed two predominate Christian groups: the deeply engrained Donatist Church located in the interior and a government-back Catholic Church found in the coastal cities. Perplexedly, however, by the last decade of the fourth century a series of events unfolded that resulted in the reduction the Donatist Christians to a community of outlaws. Much study has already been performed about the historical circumstances for why Donatist Christianity essentially disappeared from history, and more than once it has been suggested that this decline was the result of failed episcopal leadership. Therefore, this morning, I will provide a synthesis of results from my research paper about whether or not it was the election of Primianus in 392 as the last Donatist Primate of Carthage that initiated the end of Donatist Christianity.

First let me explain the limiting factors to my investigation. One problem is that few records exist about Primian himself and ones we do have were transmitted through Augustine and can thus be scrutinized as being biased. Additionally, there is no extant record about the election of Primian. Even further, most modern research has tended to portray Primian in a very negative light. So it is indeed difficult to research this matter. However, because of Augustine we have today a record of two Donatist councils after Primian's election, a result of the so-called Maximian schism (which was led by an opposing deacon by the name of Maximian), from which we can garner an assessment, of these two councils one was condemnatory of Primian and the other was redemptive.

The record of the councils, which were held in two small cities in modern-day Tunisia, indicates that Primian was condemned shortly after his election for a number of improprieties, including reconciling schismatics without re-baptism (which was a serious offense to Donatists), physical intimidation and assault on ideological opponents, and denial of the sacraments to those not in agreement with Primian. In sum, Primian was accused of having committed very serious sins and therefore needed to be expelled from the Donatist Church in order to protect its purity, which was a central Donatist precept. Primian's condemnation was 
then followed up with a council that was convened in his favor and that excommunicated those leading the Maximian opposition against him. And before I go further, Id like posit two possible explanations for the trouble that occurred after Primian's election. It seems plausible that the reason for the controversy surrounding the election of Primian was either a result of either (1) intra-regional tensions or perhaps (2) a back-lash against his predecessor Parmenianus. Regarding the first possibility, there is some evidence that shows that bishops who opposed Primian, who came from modern-day Libya and Tunisia tended to be more moderate in their positions while bishops who supported Primian, from modern-day Algeria and Morocco, tended to be much more stalwart in their Donatist faith. This is also perhaps a reflection of possible ethnic differences at the time, as the first group was called 'Libyan' and the latter group much more affiliated with who we today call the Berbers. This could even be better understood if it were possible to conclude that Primian represented the proto-Berbers and his opponent Maximianus represented the Roman or Libyan groups.

Concerning the possibility that the controversy surrounding Primian's election was a backlash against a particular ideology, it seems that there is room to say that it is within the realm of possibility that there could have been a rift between North Africans who found Parmenian's earlier efforts at developing a 'gifts of the church' theology that moved Donatist thinking away from seeing their church as the 'church of the pure' towards the 'collecta of Israel'. Donatists prided themselves on strictly interpreting their theology which they believed remained undiluted from Cyprian's time on. Therefore, it does not take an over-imaginative mind to see such rigidity would not have welcomed much theological latitude. I find evidence of this in the rejection of Tyconius by the Donatist leadership already at a council in 385 for taking Parmenian's leads a step further by crafting a church-model of a 'corpus permixtum', which incidentally Augustine and the Catholics would later adopt. Afterwards, a gradual narrowing of outlook was traceable among Donatist thinkers.

What occurred after these two councils is a bit clearer and equally if not more cogent for my purposes. After the second council, Primian initiated a multi-year legal strategy that involved using the Roman imperial administration to penalize and disband his opponents, which is an interesting turn of events given the historical Donatist distrust of the secular world. This legal strategy focused on having the enemies of Primian declared as heretics and 
therefore liable to prosecution under the Theodosian anti-heresy laws. In the short term Primian was successful in applying this legal strategy, but would eventually come-up short as the Roman Empire placed greater emphasis on controlling affairs in North Africa in the face of pressure resulting from immigrating Germanic groups from the north. Likewise, a new generation of Catholic bishops, led by Augustine, initiated a sustained anti-Donatist offensive that would eventually be successful.

The core of Augustine's efforts was to criticize elements of the controversy surrounding Primian's election. Augustine's arguments, which would be used continually through his antiDonatist works, were that (1) Primian had refuted the Donatist doctrine of re-baptism by his relaxed standards of readmission of schismatics at the beginning of his episcopacy, (2) had refuted Donatist ecclesiology by his liberal integration of the Roman Empire in ecclesial matters for the purpose of church re-unification, and (3) that Primian had in fact repeated the same errors as they accused the Catholics of at the beginning of the Donatist Schism in 312, that is by refusing to expel clergy who stood to contaminate the purity of the Church. So in this sense once could say the decline of Donatism, in terms of intellectual undermining, had some beginnings in Primian's election.

And while the combined strength of Augustine's polemical arguments against Primian were indeed effective later on, it was the Catholic adoption of the Donatist legal strategy (that is, appealing to the Roman government to apply the Theodosian laws) that would spell out the end of Donatism as an existential reality. This was done by having the Roman government recategorize the Donatist Church as illegitimate in a series of imperial maneuvers in 403.405, and culminating at a council in Carthage in 411. Therefore with this in mind, one cannot help but notice that Donatist Christianity was indeed disbanded after unparalleled prosperity, all within the timeframe of Primian's episcopacy.

\section{Conclusion}

To conclude I sought to ascertain whether or not the election of Primian as Bishop of Carthage as the gateway to the end of the Donatist Church. Despite the acknowledgment of a scarcity of information about Primian himself and an exclusive reliance on Augustine, it was possible for me to make some critical evaluations. The Maximian schism, which seems to 
have been a result of the election of Primian, manifested serious foundational shifting within the Donatist Church and handicapped Primian's mandate to lead his co-religionists, especially at a time when the Catholic Church was reorganizing itself in North Africa and the Roman Empire began to be much more assertive in matters of enforcing orthodoxy. I analyzed how the Maximianist accusations against Primian were a stimulant for Augustine, whom it seems used this intra-Donatist affair as a springboard for his own anti-Donatist effort. This is evident from the recurring themes of his polemical writings in the 400s, which were particularly focused on rebaptism, the legitimacy of Caecilian's condemnation, and the separation of the church from the world. We lastly saw Primian's stature was diminished even before 411 as the Catholic party repeatedly succeeded in drafting the imperium into condemning the Donatists using the Donatists' own legal-appeals method.

From what has been gauged here, an important question can be proffered: was Primian's behavior so vicious so as to have caused Donatism's collapse by his allegedly scandalous ways and unscrupulous use of secular power to condemn his enemies? In other words, did Donatism end, as, more-or-less, a result of Primian's actions as the last Donatist primate? This leads me to assert a conclusion in the negative, but a qualified negative.

I conclude that while there is much reason to accept the legitimacy of the Maximianist condemnation of Primian's conduct (and that it was not solely a polemical contrivance), that was not in and of itself enough to bring down the house. Mindful that the Donatists themselves considered the Maximian schism to be a family matter, it would have likely been sorted out in house. In this case, it seems feasible this could have simply been a squabble over regional tensions or a reaction to the theological liberalization under Parmenian and Tyconius. Even Primian's recourse to the Roman legal system was not in and of itself enough to cause the decline of Donatist Christianity. There are repeated examples from North African history when Donatist bishops made recourse to Rome for its imperial validation, but those occurrences never extinguished their organizations' fecundity. The fact that it was the Catholic usurpation of the same legal strategy implemented by Primian that eventually brought down the heavy-fire needed to suppress Donatism is less a matter of calculus then it is that Donatists simply had the force of history stacked against them.

But Primian is not to be let off of the hook completely. Though while it is true there where movements at work beyond his control, the case must be made nonetheless that Primian's 
initial failures and inability to hold together his rambunctious church as his predecessors did in similar circumstances did set the stage for Augustine's polemical technique to ripen. One need only consider how Augustine's initial anti-Donatist works rang hollow in North Africa. Indeed, it was only after the Maximian schism that as a bishop, Augustine could capitalize on the theological opportunities of the Maximian crisis. Perhaps it is this that explains, at least in part, the intensification of Augustine's writings and the increased efficaciousness of his arguments? Regardless, Primian's records warrants a more objective consideration, that is, while committing many grievous errors in leadership, his election as Bishop of Carthage was not in and of itself the beginning of the end of Donatist Christianity. 